\title{
THE GAMETOPHYTES OF EQUISETUM LAEVIGATUM ${ }^{x}$
}

\author{
E I D A R. W A L K E R
}

(WITH PLATES XXIII, XXIV AND THREE FIGURES)

\section{Introduction}

According to Buchtien (I), gametophytes of Equisetum were first found by VAUCHER in I826, and later by BISCHOFF in I829, and MILDE in $185^{2}$. The finding of Equisetum gametophytes, however, has been rare. When in August I9I6, Robert A. NeSBit, at that time a student in the University of Nebraska, found large numbers of them near Tekamah, Nebraska, it was hardly expected that the discovery would soon be repeated. The gametophytes, however, have since been found in several localities, usually in Nebraska, by a number of persons. At the suggestion of Dr. CharLes J. CHAMBERLAIN the writer undertook a study of these gametophytes with the results here reported.

\section{Distribution}

The discovery of Equisetum gametophytes by Mr. NesBit called the attention of local botanists to the possibility of finding them. The result is that they have been observed in recent years as follows:

Robert A. Nesbit, Tekamah, Nebraska, August and September 1916; N. F. Petersen, Osborn, Indiana, August 2, I9I7; Manhattan, Kansas, September I9I 7; Reno, Nevada, July 1918; Pilger, Nebraska, September 25, I920; Lincoln, Nebraska, October 9, I920; Florence, Nebraska, November 5, 1920; South Sioux City, Nebraska, November 7, I920; F. C. Jean, Peru, Nebraska, August 1917; Elda R. Walker, Doris Hayes, and Katherine Wolfe, Lincoln, Nebraska, October I2, I7, 24, and November I4, I920.

Since learning of these recent observations, Professor O. A. Stevens has told the writer of finding a considerable number of Equisetum gametophytes on the banks of the Big Blue River and a drainage ditch emptying into it, at Manhattan, Kansas, in Septem-

${ }^{x}$ Contributions from department of botany, University of Nebraska, new series, no. 33 .

Botanical Gazette, vol. 7r] 
ber igo8. Mrs. T. J. Fitzpatrick also found large numbers of them on the banks of the Iowa River at Iowa City, Iowa, during the years I884-1888. At Osborn, Indiana, Manhattan, Kansas, and Reno, Nevada, Professor N. F. Petersen found only a few specimens. At all other points, except Lincoln, they were present in large quantities. They were on the banks of every creek but one examined in the neighborhood of Lincoln, but were not abundant in any place. Mr. Nesbit describes the habitat in which they grew at Tekamah, Nebraska, as follows:

These were found along both banks of a typical prairie creek from the point where it emerges from the hills for a distance of at least four miles upstream. They occurred almost continuously throughout this distance. The creek is subject to overflow several times a year, and has built up a narrow floodplain of rich soil. The creek bed itself is about $15 \mathrm{ft}$. below the level of the floodplain, and is shaded by trees throughout most of its course. Near the water there is usually a belt of mud or very moist soil, varying in width from a few inches to several feet, and sloping gradually upward to the beginning of the more precipitous slope of the banks. . . . . The gametophytes, varying in size from I $\mathrm{mm}$. to about $\mathrm{I} \mathrm{cm}$. in diameter, occurred on this mud. They were abundant, in many places being separated by an average distance of not more than $3 \mathrm{~cm}$. In other places they were more scattered, and occasionally, where the mud belt was too soft, they were lacking entirely. . . . . There were very few other plants growing in this mud belt, Riccia being the only form that appeared constantly.

For all the localities in Nebraska, Kansas, and Iowa the same description in general holds true. They were found along streams of all sizes, from the smallest creeks and drainage ditches to the Missouri River, and in all cases were on the mud belt and associated with Riccia. At Osborn, Indiana, the gametophytes grew in a ditch by a railroad on soil where ties had been burned. This had destroyed other vegetation, and mosses were just starting with the Equisetum. At Reno, Nevada, they were growing beside a waterfall.

\section{Identification of species}

In no case in Nebraska were mature Equisetum sporophytes found on the creek banks on which the gametophytes were growing. As a rule the only spore-producing plants within many miles were $E$. arvense and $E$. laevigatum, strictly prairie forms. Spores of $E$. arvense, $E$. robustum, and $E$. laevigatum have been grown in 
culture, and the wild gametophytes were compared with them. They resembled closely the two latter, but were definitely different from $E$. arvense.

In eastern Nebraska but two other species of Equisetum are known, E. robustum and $E$. variegatum, according to FITZPATRICK (4). Of these E. variegatum is rare; E. robustum is seldom found except along the banks of the Missouri River and its larger tributaries. The gametophytes found on the river banks at Florence and South Sioux City were slightly larger than the others and might belong to this species. FitzPatrick, however, who examined the young sporophytes of all of the collections, failed to find on these evidence of the characters of $E$. robustum. Like those of all the other Nebraska gametophytes, he found that they resembled more closely E. laevigatum. These last bore so many large sporophytes that the gametophyte tissue was badly disorganized and of little use for study; consequently the microscopic studies were limited to the gametophytes from Tekamah, Pilger, and Lincoln. As at these places $E$. robustum is not present, and as the gametophytes do not resemble $E$. arvense, they are undoubtedly $E$. laevigatum.

The gametophytes from Osborn, Indiana, are without question E. arvense. Adult plants of the species occurred near by, and the gametophytes agree with those grown in culture. Those from Manhattan, Kansas, Iowa City, Iowa, and Reno, Nevada, were not seen by the writer, nor were those from Peru, Nebraska. Abundant specimens from the other localities, however, have been examined. ${ }^{2}$

\section{Gametophytes}

The gametophytes appear as circular cushions (figs. I-5, 7, Io, and text fig. I) varying in diameter from I $\mathrm{mm}$. to $\mathrm{I} \mathrm{cm}$. They are a dull green with a slight brownish tint, making them inconspicuous as they grow on the wet soil. In many cases the writer looked at a given spot several seconds before her eye differentiated the form of the gametophytes, even where there were some of the larger ones. This may account in part for their not having been found more frequently.

${ }^{2}$ Sections made by Stevens of the gametophytes found by him at Manhattan, Kansas, have been examined. These agree entirely with the gametophytes of E. laevigatum. 
Each gametophyte consists of a flat circular disk (shown entire in fig. 6, which is a ventral view, and in section in figs. 8 and 9) of large-celled compact tissue I-IO $\mathrm{mm}$. in diameter and bearing many upright green branches on its upper surface. It is usually indented deeply at one side (figs. I, 5, 6) and may be more or less lobed at the periphery, where it is surrounded by a heavy band of meristem (figs. 6, 8, 9) so long as growth continues. This meristem is often more active at some points than at others, which causes the marginal lobing. Fig. 6 shows the under side of the gametophyte whose upper surface is shown in fig. $\mathrm{I}$. The thallus was killed and

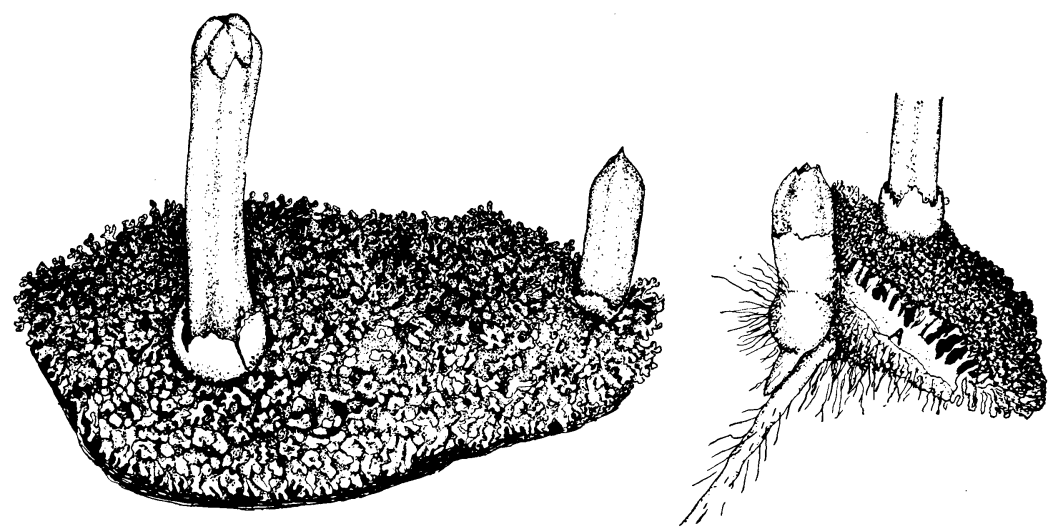

FIG. I.-E. laevigatum: at left gametophyte with two sporophytes; at right gametophyte with sporophyte having developed a second shoot and root; gametophy te tissues cut away at $A$; section of sporophyte shown in fig. II; $\times$ Io.

cleared in glycerine and then photographed from below to show the meristem band about the periphery and the slight lobing often present. It is this peripheral meristem that continues the growth of the thallus and gives rise to the upright branches and the sex organs. Fig. 8 shows this meristem at each end of the section producing archegonia. Fig. 9. shows the same structure, but at the left the meristem band contains two antheridia, and at the right a sporophyte with foot, root, stem, and leaves differentiated. The entire upper surface of the thallus is covered by the upright green branches. These branch more or less above and are wider at the tip than at the base (fig. 8). Very little chlorophyll is present in the 
large cells composing the disk. The under surface is richly supplied with rhizoids.

The gametophytes are typically monoecious. Over fifty specimens of all sizes have been examined in paraffin sections and a large number of others in freehand sections, and still others without sectioning. None has been found without old archegonia. Many, about 30 per cent, also bear antheridia that are still active, and others show the scars of antheridia that have discharged their sperms. Only in a few cases was it impossible to find some trace of

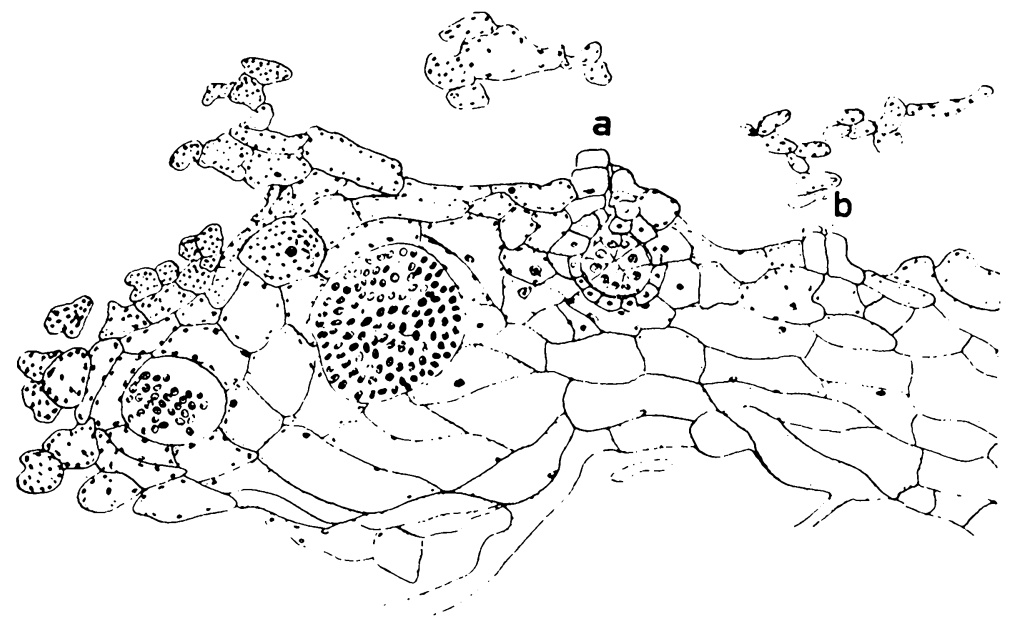

Fig. 2.-E. lacigatum (vertical section): at left two mature antheridia; at $a$ archegonium containing young sporophyte; at $b$ neck cells of functionless archegonium; $\times 75$.

them. Antheridia, archegonia, and sporophytes often show in the same section. Fig. 9 shows antheridia on the left and a sporophyte on the right. The same thallus showed in other sections young and old archegonia. Fig. I7, whose detail is shown in text fig. 2, shows a vertical section through the periphery of a thallus. At the left are two mature antheridia. At the center above at $a$ is an archegonium containing in its venter a young sporophyte of about thirty-two cells. At $b$ are the four neck cells of an old functionless archegonium. Text fig. 3 shows part of a section of another thallus. On the left is a young antheridium in which the sperm 
mother-cells are not yet differentiated. Two cells to the right of it is the venter of an archegonium surrounded by its jacket cells and containing a mature egg cell. Above at $a$ are the neck cells in oblique section.

Figs. I 2 and $\mathrm{I} 3$ are near sections, cut horizontally. In fig. I 2 are shown twelve antheridia in various stages of development.

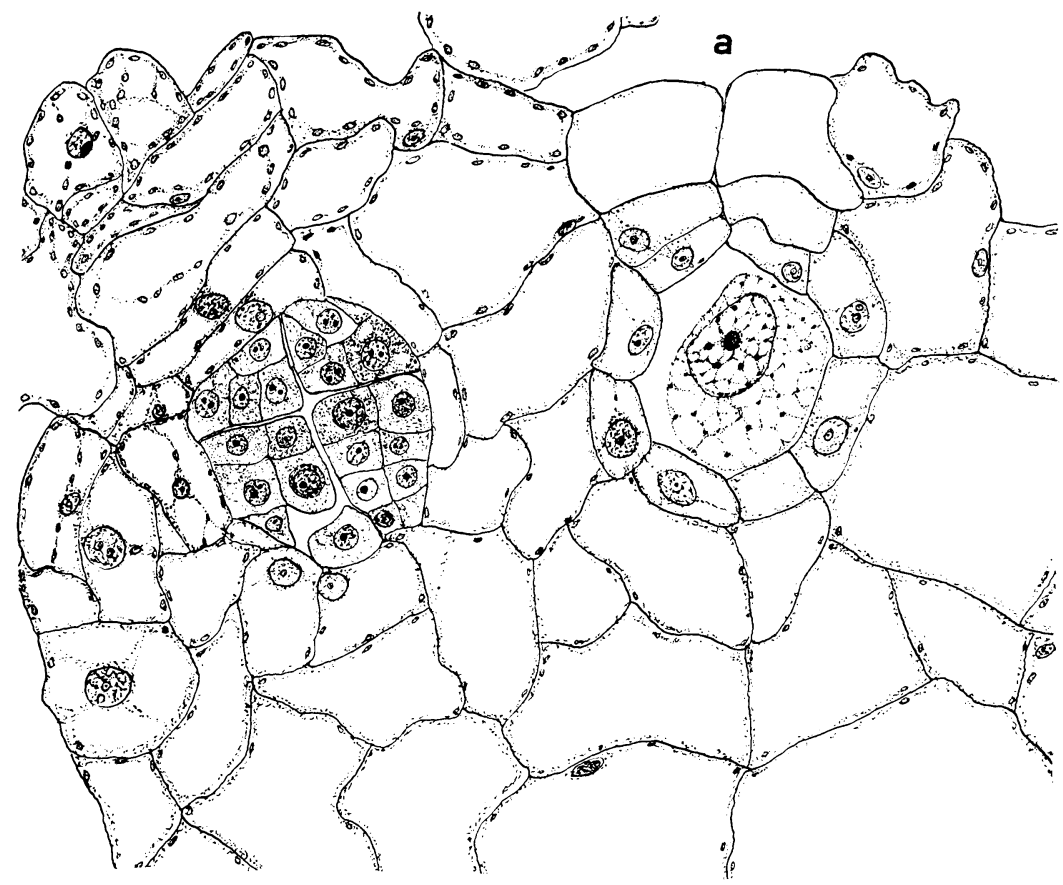

FIG. 3.-E. laevigatum (vertical section): at left young antheridium; at right archegonium with egg; below $a$ neck cells cut obliquely; $\times_{3} 80$.

In the smaller lobe only two cells from a young antheridium is the neck $(a)$ of an archegonium, whose venter containing a mature egg is shown in a deeper section, fig. $\mathrm{I}_{3}$ below $a$. Fig. I4 shows a vertical section of an archegonium containing a young sporophyte. Fig. I 5 is a vertical section showing two mature antheridia at the left. Directly below $a$ and $a$ are the necks of two old archegonia that have failed to be fertilized. In fig. I6 above is a mature antheridium and a very young one. At the extreme left $(B)$ and 
also to the right $(B)$ of the lobe bearing the antheridia are old antheridia whose outer walls have broken away. Some sperm cells are still present. At the extreme right below $a$ is one of the four neck cells of an old archegonium whose venter has become brown with age. This same method of antheridial dehiscence is shown in fig. $\mathrm{Ig}_{9} B$.

On the peripheral meristem young archegonia or antheridia or both (figs. 8, 9, I 2-r9, text figs. 2, 3) develop so long as the meristem continues its growth, but are not distributed in any definite way. In some individuals only one kind of sex organ will appear throughout the entire periphery, while on others certain lobes develop archegonia and others antheridia. On still other gametophytes archegonia and antheridia occur together (text figs. 2, 3 and figs. I2, I3, I5, I7), mixed indiscriminately around the entire meristem ring on the various thallus lobes. One gametophyte, for example, bore eleven sporophytes in various stages of development, fifteen active antheridia, and numerous archegonia in all stages, from old functionless ones to those still in stages of development. In the gametophytes from Tekamah, Nebraska, of the 30 per cent bearing young active antheridia 70 per cent also bore sporophytes. Those from other localities showed approximately the same condition.

Old ruptured antheridia and old archegonia show within a few cells of young active sex organs (figs. I5, r6, I7). When the antheridia mature and discharge their sperms, the outer wall breaks away, leaving but a slight scar in the tissue. The other tissues may or may not push up over this. In the former case the walls of the antheridium collapse and show as a brown line between the vegetative cells; in the latter case the scar is only a ragged break in the periphery (figs. I6, 19). These are recognized with difficulty, which no doubt accounts for the apparent absence of old antheridia on some of the thalli. On many bearing only archegonia, however, it was possible to indentify definitely the scars of old antheridia. There were a few actively growing individuals on which antheridia were not definitely located. In the case of gametophytes bearing large or numerous sporophytes, the tissue was so shrunken and broken down that it was often difficult to identify old arche- 
gonia, which are usually conspicuous, and in such cases no traces of antheridia could be found.

In general it seems that the thallus continues to grow, forming new sex organs until sporophytes have developed to such an extent that the tissues are exhausted. If a sporophyte starts when the thallus is small, one rarely finds young sex organs developing later. If, however, fertilization does not occur, the archegonia dry up and new ones, and often antheridia also, are formed until fertilization is accomplished. If the thallus has attained considerable size before any fertilization occurs, a large number of sporophytes may be supported by it without injury, and in such cases the development of sex organs may continue until many archegonia have been formed and fertilized, and until the sporophytes are well advanced. The sporophytes invariably occur near the periphery, as shown in figs. 4, 7, 9, ro, and II of the thallus, while old functionless archegonia often show between the branches entirely across the surface.

The younger sporophytes are nearer the edge of the disk, and the active archegonia and antheridia are in the peripheral meristem (figs. 8, 9, r2-r9, and text figs. 2, 3). Eleven sporophytes in early stages have been seen on. one gametophyte, but not more than seven have been found sufficiently large to be seen by the unaided eye. In a few cases dead young sporophytes were observed, but in the majority of cases they looked in good condition. As the growing season was nearing its close, however, it is hardly probable that sporophytes not yet having secured a foothold in the ground could mature.

Bischoff, according to Buchtien (I), reported finding monoecious gametophytes of $E$. sylvaticum bearing archegonia on their older parts and antheridia on the younger parts, and stated that monoecious gametophytes are not so rare as commonly believed. He found them occasionally in all his cultures. He also found the gametophytes of $E$. sylvaticum to be largely male, but many bore archegonia, and among these a comparatively large percentage bore antheridia also. He considered that the antheridia were formed after archegonia ceased to develop, but some bore them on different parts of the spreading meristem at the same time. 
Kashyap $(\mathbf{7}, \mathbf{8})$, however, describes for $E$. debile much the condition found in these gametophytes of $E$. laevigatum, except that he rarely found antheridia occurring on gametophytes bearing sporophytes. Evidently the gametophytes examined by BuchtiEn and KaSHYAP very closely resembled those of $E$. laevigatum under consideration.

\section{Sex organs}

Archegonia (figs. 8, I3, I4) were present in all stages of development and agree closely with those described by Buchtien (I), Sadebeck (9), Campbell(2), Hofmeister (5), Goebel(3), and others. The only point of disagreement as to the archegonia of Equisetum appears in connection with the neck canal cells. In E. laevigatum the condition does not seem uniform. In many cases there is evidently only one neck canal cell. In a few archegonia, however, the vertical division had occurred and given rise to the two characteristic boot-shaped cells. The archegonial initial appears at any point on the peripheral meristem, not always on the under side, but in all cases the archegonia are pushed to the upper surface by the growth of the meristem below (figs. 8, I4). Branches usually develop at each side of an archegonium (fig. I4), so that when mature it lies between two branches.

Antheridia in large numbers also were present in all stages. They showed but one type of development, that characteristic of eusporangiate ferns. In the examination of more than fifty gametophytes in paraffin sections, only half a dozen antheridia were found on the upright branches. These (fig. I8), however, were not at the tip of the branch, but showed definitely the same development as others, which were developed in the massive meristem at the periphery of the thallus (figs. 9, I2, I3, I $5^{-1} 7$ ). It is interesting to note that Buchtien ( $\mathbf{I}$ ) considers even the antheridia developing at the tips of branches to be of the eusporangiate type. He says it seems that the antheridia at the tip of a filament and those in a cell mass develop differently, but it is only an apparent difference. In a filament there are no suitable conditions for antheridial development, so three vertical walls cut out surrounding cells which take the place of a thallus mass. Then the real antheridial initial is not the end cell of the filament, but the tetrahedal cell surrounded 
by the three cells. This cell divides transversely and forms an antheridium exactly as is the case in the antheridia produced in the tissue. This is an interesting interpretation of the development of antheridia at the tip of a slender branch. As no such antheridia were found in these wild gametophytes, however, it does not apply to this case. The antheridia open by the disorganization of the entire outer wall as previously mentioned. In E. laevigatum, as was found by KaShyap ( $\mathbf{7}$ ) to be the case in E. debile, antheridia often occur between the upright branches in exactly the position characteristic for archegonia. Figs. I2, I 5, I7, and I9 show the beginning of these branches between antheridia.

\section{Embryo}

Embryo sporophytes in all stages, from a few cells to those with the third shoot an inchlong, were abundant in most of the collections. The development was entirely characteristic of that commonly described for the group (JEFFREy 6, and others)(figs. 9, I I and text fig. I). The number of leaves on the primary shoot varies from three to four, and on the second shoot from four to five. Fig. I4 shows a very young sporophyte at about the r6-cell stage. In fig. I7 and text fig. 2 the sporophyte is still larger, while in fig. 9 the sporophyte shows all the body regions well organized. Fig. Ir, a section of the plant shown at the right in text fig. I, shows the primary branch well developed, with its first whorl of four leaves at the base. Its root emerges from the ventral side of the thallus. In text fig. I (at the right) part of the periphery of the thallus was cut away at $A$, where the cut surface shows. At the left of the gametophyte to the right in text fig. I and at the right of fig. I I is the second shoot with several whorls of leaves and with its root emerging below. In this specimen the leaves on the second shoot were four in a whorl, the same as on the first shoot. In fig. I the bud for a third shoot shows at $B$. In text fig. I the sporophytes also show four leaves on the first shoot. This, however, was not universally true, many showing but three leaves (figs. 4, 7, ro). The roots for these shoots were well developed and deeply buried in the soil. Plants transferred to pots in the greenhouse are still growing vigorously (March I). 


\section{Culture method}

In connection with the study of the wild gametophytes, spores were planted in flats in the greenhouse and studies of young gametophytes and their development are under way. For a number of years gametophytes of $E$. arvense have been grown with considerable success. Each year sporophytes have lived until the primary shoot was a couple of inches tall, and in some cases the secondary shoot has developed. Because of this the same culture method was tried with $E$. laevigatum. The method used was as follows. An ordinary greenhouse flat was filled with sifted soil, a mixture of loam and sand being used. The soil was then smoothed and pressed down until a firm hard surface was formed an inch or more below the top of the flat. This was then flooded with water and allowed to stand until the water sank into the soil. Just as the water sank to the top of the soil the spores were shaken from the cones on to the soil. This was done by tapping the cone hard enough to shake the spores from the sporangia. The flat was then covered with a piece of glass and set in a sunny room of the greenhouse. Usually no more water was needed until the gametophytes were I $\mathrm{mm}$. or more in diameter. If, however, the flats became too dry, they were watered by holding them in a tank of water until the soil became wet from below. After the gametophytes were I $\mathrm{mm}$. in diameter they were sprinkled with an ordinary garden sprinkler. No attempt was made to sterilize the soil, nor were any special methods of watering used.

Flats of E. laevigatum planted in this manner in the middle of June grew well and developed archegonia and antheridia until the first of September. During the writer's absence of two weeks the greenhouse attendants changed and the flats were permitted to dry up. All were killed except one flat, in which sifted cinders from a railroad track were used instead of the usual soil. This flat survived the drought, and during the middle of September was full of sporophytes. Slugs ate these off as fast as they grew, however, so that none reached a height of more than a few millimeters. The gametophytes continued to grow, however, and new sporophytes developed only to meet the same fate. As winter approached the growth became slower and new sex organs did not 
appear. Many gametophytes died, while others continued a sluggish growth. They are still alive (March I) and show some growth, although on the whole no increase in size is observable.

By this same method spores of E. arvense, E. telmateia, and $E$. robustum sent from western Oregon, and of $E$. arvense from Chicago were also grown. These spores were planted about a week after gathering, and all grew well. E. arvense and E. telmateia developed sporophytes freely, but $E$. robustum never developed sporophytes, although the thalli lived until September I and attained a diameter of nearly I $\mathrm{cm}$. before they died.

The fact that these spores grew well led the writer to plan some experiments in order to test the vitality of spores. Cones were taken when so green that the spores would not leave the sporangia. The cones were crushed and sprinkled on the soil. Others were planted when the spores were just ripe. Still others were kept in the laboratory in an open box for nine days. The cones were so dry they could be pulverized between the fingers when they were planted. In all cases equally abundant germination was observed, but the older the spores the longer the period before germinaton took place. Spores from green cones produced gametophytes of two and three cells during the first twenty-four hours, while gametophytes from spores dried for nine days required a week or more to reach the same stage. After being started they also developed more slowly. This agrees with Buchtien's results. He found that after fifteen days germination decreased greatly, and after twenty-one days only about I per cent germinated, and the growth was much slower. Studies of these gametophytes and their development are in progress, and the results will be given in another paper.

\section{Summary}

The investigation of large numbers of gametophytes of $E$. laevigatum found growing in their native habitat yielded results which may be summarized as follows:

I. The gametophytes are all of one kind.

2. They consist of a flat circular disk $\mathrm{I}-\mathrm{IO} \mathrm{mm}$. in diameter bearing numerous upright green branches on their upper surface, 
and surrounded by a band of meristem which continues the growth of the thallus and produces archegonia and antheridia.

3. The gametophytes are typically monoecious. All bear archegonia and many antheridia also. Antheridia and archegonia occur without order on the thalli and often within a few cells of each other and of sporophytes.

4. Antheridia and archegonia may continue to develop until one or more sporophytes have attained considerable size.

5. Antheridia all develop as is characteristic of eusporangiate ferns, whether in a massive tissue or on a slender branch.

6. Archegonia develop as is characteristic of the group.

7. Sporophyte development is in agreement with common descriptions. The leaves of the first shoot are three or four in number, of the second shoot four or five.

8. Gametophytes grow to maturity under simple methods of culture.

The writer is indebted to Professor Charles J. Chamberlain for his interest and helpful suggestions during the progress of these studies, and for spores for culture growth; also to Mr. C. T: WALKER for spores sent from western Oregon, to Professor T. J. FitzPatrick for the identification of sporophytes and for the careful reading of manuscript and proof, and to Mr. GEORGE Swale, without whose efficient care of the greenhouse and cultures the experiments could not have been carried out.

UNIVERSITY OF NEBRASKa

LiNCOLN, NEB.

\section{LITERATURE CITED}

I. Buchtien, Otтo, Entwicklungsgeschichte des Prothallium von Equisetum. Bibliotheca Botanica 8. I887.

2. Campbell, D. H., The structure and development of mosses and ferns (Archegoniatae). New York. I895.

3. Goebel, K., Organography of plants. Transl. by I. B. Balfour. Oxford. I900.

4. Fitzpatrick, T. J., The fern flora of Nebraska. Amer. Fern Jour. Io:6-I 5, 34-44. 1920 .

5. Hofmeister, W., The higher Cryptogamia. Ray Soc. transl. by F. CURREY. I862. 

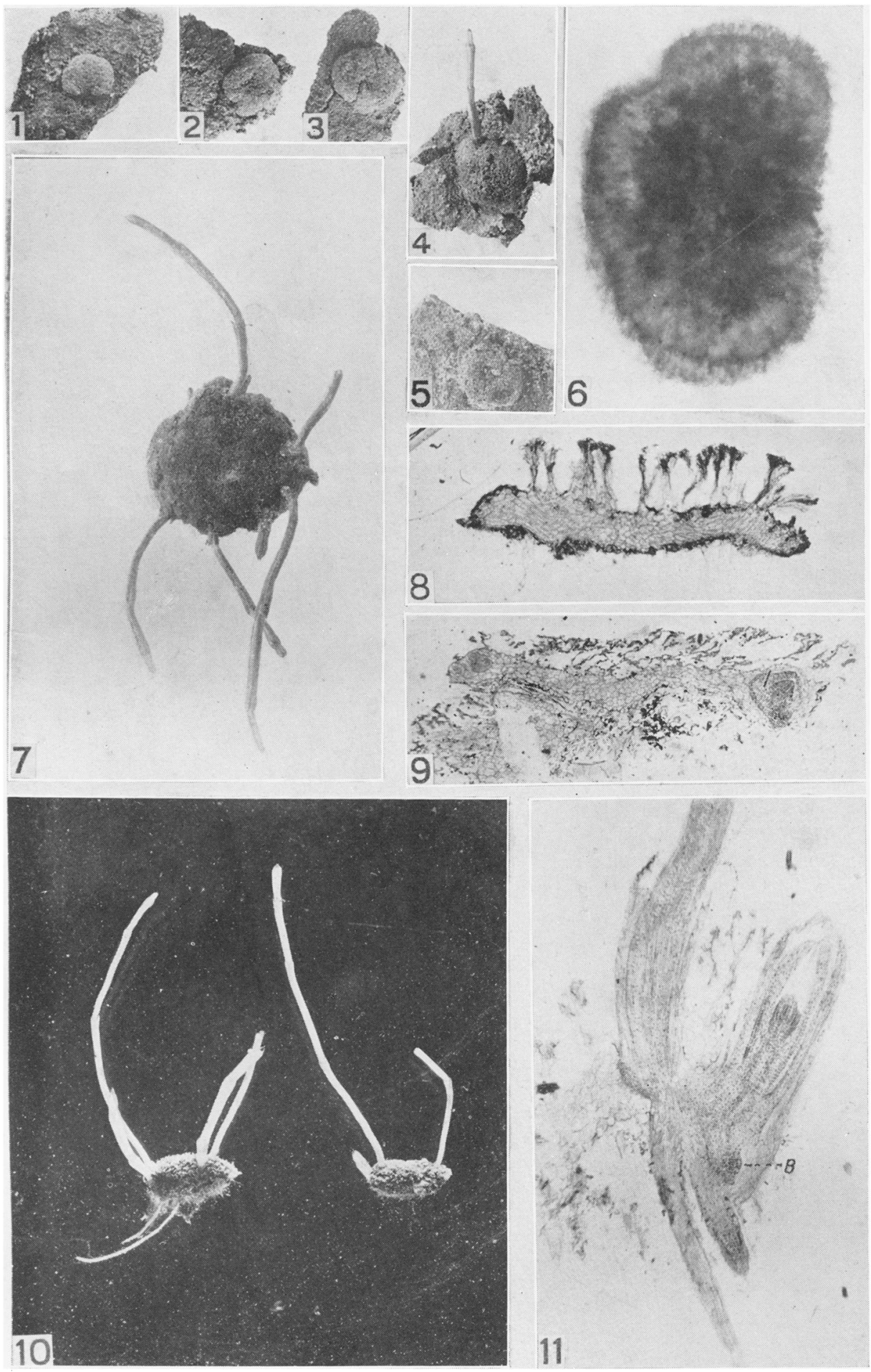

WALKER on EQUISETUM

This content downloaded from 128.248.155.225 on November 27, 2016 09:01:01 AM All use subject to University of Chicago Press Terms and Conditions (http://www.journals.uchicago.edu/t-and-c). 

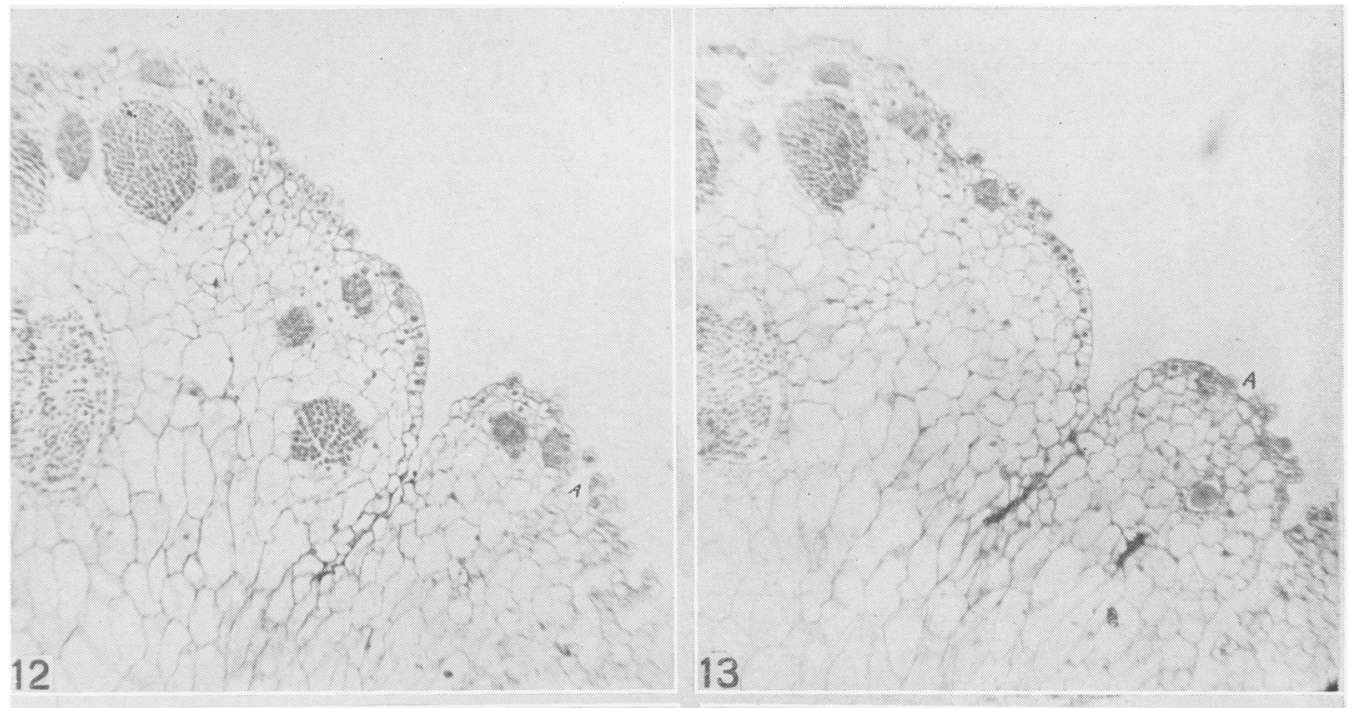

14

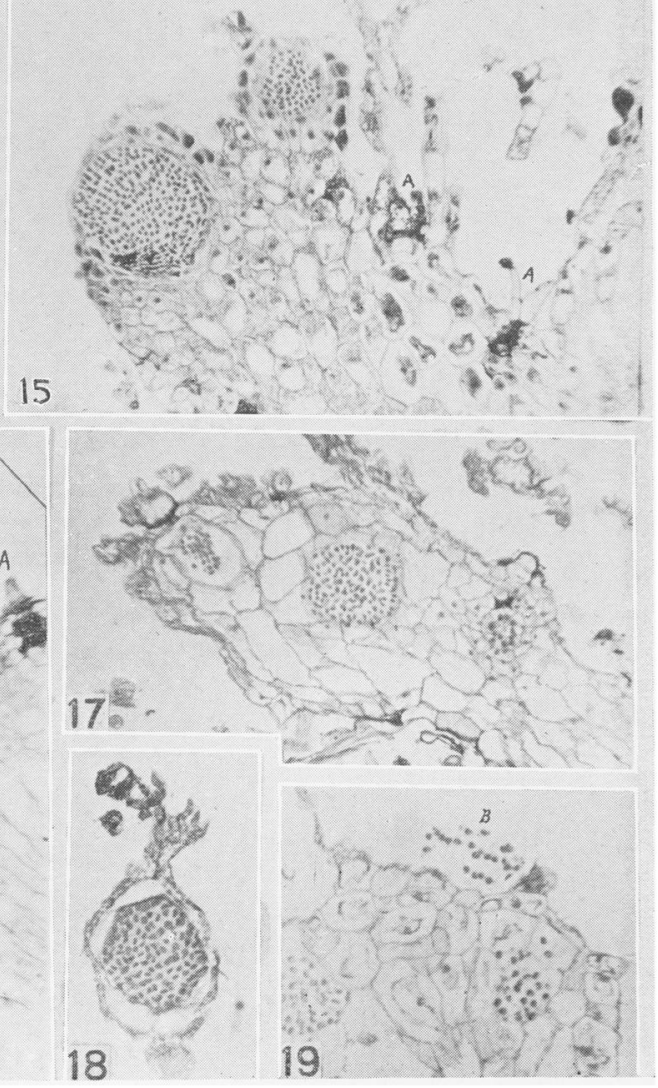

16
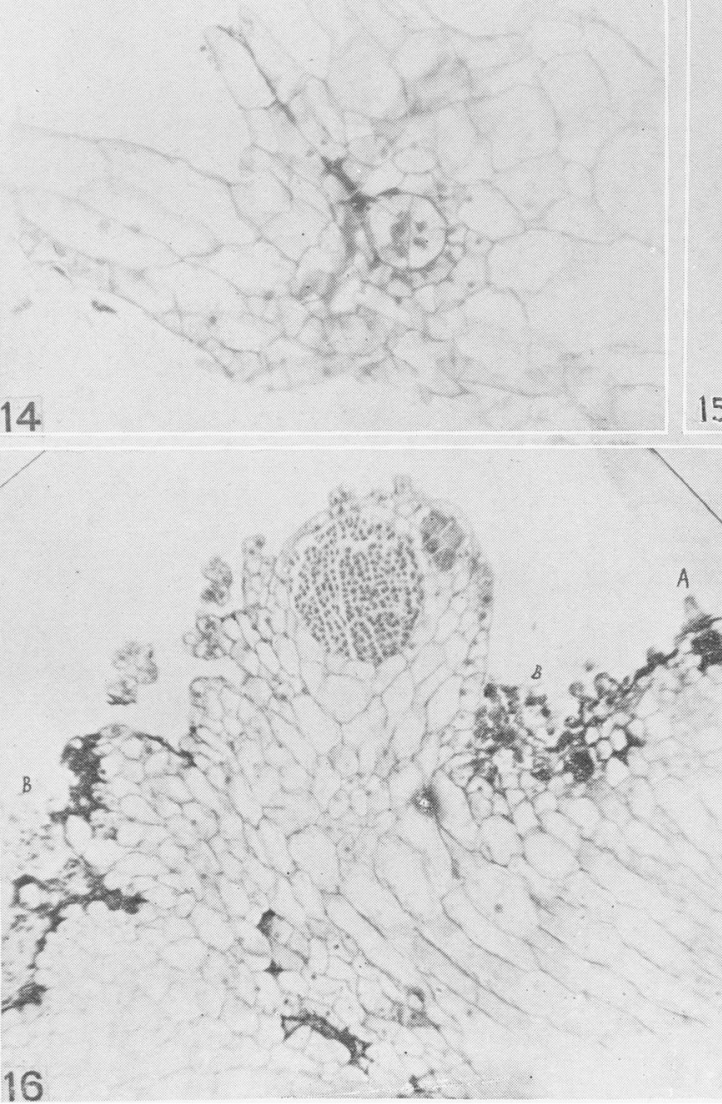

WALKER on EQUISETUM

This content downloaded from 128.248.155.225 on November 27, 2016 09:01:01 AM All use subject to University of Chicago Press Terms and Conditions (http://www.journals.uchicago.edu/t-and-c). 
6. Jeffrey, E. C., The development, structure, and affinities of the genus Equisetum. Mem. Boston Soc. Nat. Hist. 5: no. 5. I899.

7. Kashyap, Shiv Ram, The structure and development of the prothallus of Equisetum debile Roxb. Ann. Botany 28: I63-I8I. I9I4.

8. - - Notes on Equisetum debile Roxb. Ann. Botany 31:439-445. I9I7.

9. SADEBEck, R., Die Entwickelung des Keimes der Schachtelhalme. Jahrb. Wiss. Bot. II: 575 . 1878 .

\section{EXPLANATION OF PLATES XXIII, XXIV}

PLATE XXIII

FIGS. I-5.-Gametophytes attached to soil; $\times 2$.

FIG. 6.-Under side of gametophyte in fig. I showing peripheral meristem, cleared in glycerine; XII.

FIG. 7.-Gametophyte with five sporophytes at periphery; $\times 2$.

FIG. 8.-Freehand vertical section of gametophyte showing massive parenchyma with upright branches and peripheral meristem bearing archegonia; XI2.

FIG. 9.-Vertical section of gametophyte showing two antheridia and one sporophyte; XI2.

FIG. Io.-Two gametophytes with soil removed (photographed under water); $\times 2$.

FIG. I I.-Part of vertical section of gametophyte with sporophyte shown in text fig. I at right; $\times 18$.

\section{PLATE XXIV}

FIGS. I2, I3.-Parts of horizontal section through peripheral meristem showing twelve antheridia and one archegonium; $\times_{50}$.

FIG. I4.-Vertical section of archegonium with young sporophyte in venter; X $\mathrm{x} 20$.

FIG. I 5.-Vertical section showing at left two antheridia; at right $(A, A)$ necks of two old archegonia; $\times_{5}$.

FIG. I6.-Horizontal section; above two antheridia intact; to their right and left $(B)$ old ruptured antheridia; at extreme right $(A)$ an old archegonium; $\times 5$ o.

FIG. I7.-Vertical section showing two antheridia and archegonium containing young sporophyte; $\times 50$.

FIG. I8.-Vertical section of upright branch with antheridium below tip; $\times 80$.

FIG. I9.-Horizontal section; upper of three antheridia ruptured; $\times 60$. 